\title{
JURINU
}
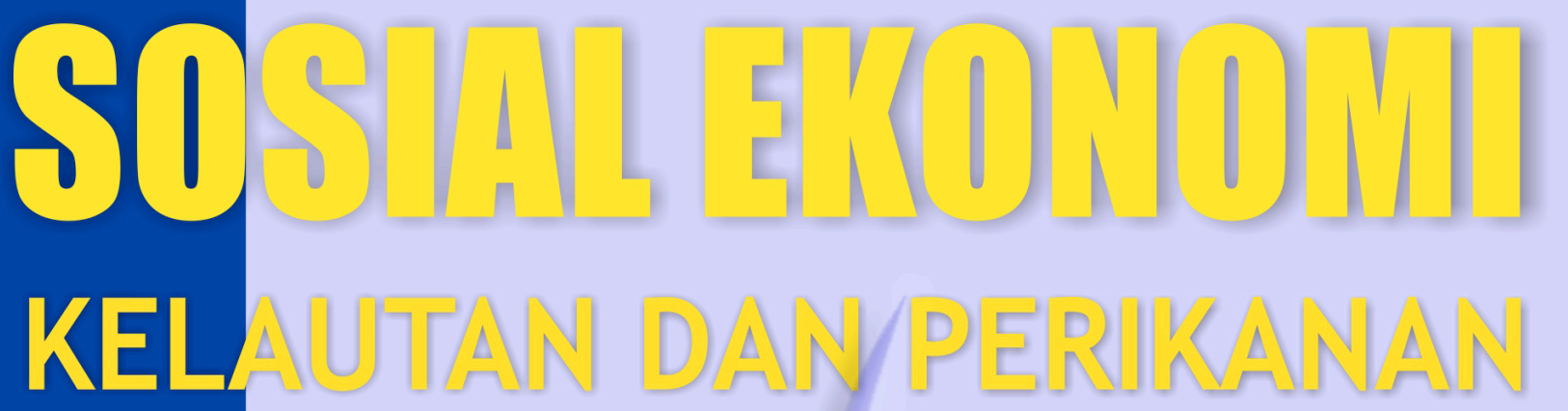

J. Sosial Ekonomi

Kelautan dan Perikanan

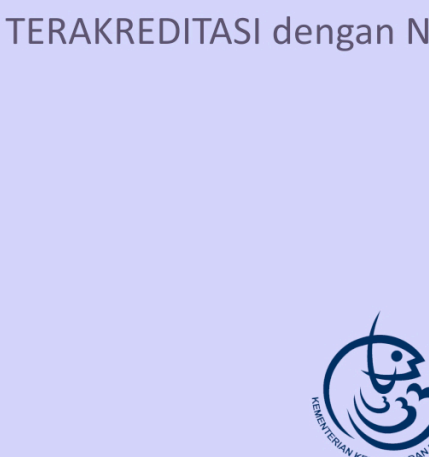

Pusat Penelitian Sosial Ekonomi Kelautan dan Perikanan

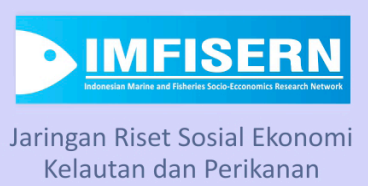




\title{
JURNAL SOSIAL EKONOMI KELAUTAN DAN PERIKANAN
}

\author{
Volume 11 Nomor 2, Desember 2016 \\ Penanggung Jawab : \\ Kepala Pusat Penelitian Sosial Ekonomi Kelautan dan Perikanan \\ Dewan Redaksi : \\ Ketua:
}

Prof. Dr. Sonny Koeshendrajana (Ekonomi Sumberdaya Kelautan dan Perikanan)

\author{
Anggota: \\ Prof. Dr. I. Wayan Rusastra (Ekonomi Pertanian) \\ Dr. Achmad Zamroni (Pengelolaan Wilayah Pesisir) \\ Dr. Rilus A. Kinseng (Sosiologi) \\ Dr. Zuzy Anna (Ekonomi Sumberdaya Alam) \\ Mitra Bestari : \\ Prof. Dr. Tridoyo Kusumastanto (Institut Pertanian Bogor) \\ Prof. Pantjar Simatupang (PSE - Kementerian Pertanian) \\ Dr. Agus Heri Purnomo (Puslitbang DSPBKP - KKP) \\ Dr. Dedi S. Adhuri (PMB-LIPI) \\ Ir. Sumardi Suriatna (Komisi Penyuluhan Perikanan Nasional)

\section{Redaksi Pelaksana :} \\ Tenny Apriliani, M.Si \\ Fatriyandi Nur Priyatna, M.Si \\ Risna Yusuf, M.Si \\ Andrian Ramadhan, MT \\ Asep Jajang Setiadi, S.Pi \\ Ilham Ferbiansyah, S. Kom

\section{Alamat Redaksi :} \\ Pusat Penelitian Sosial Ekonomi Kelautan dan Perikanan \\ Gedung Balitbang KP Lt. 3 \\ Jalan Pasir Putih Nomor 1 Ancol Timur, Jakarta Utara \\ Telp. (021) 6471 1583, Faks.(021) 64700924 \\ Email: pt.sosek@gmail.com \\ Jurnal Online: http://ejournal-balitbang.kkp.go.id/index.php/sosek
}




\section{KATA PENGANTAR}

Puji syukur kami panjatkan kepada Tuhan Yang Maha Esa karena berkat rahmatNya, Jurnal Kebijakan dan Riset Sosial Ekonomi Kelautan dan Perikanan yang berganti nama menjadi Jurnal Sosial Ekonomi Kelautan dan Perikanan dengan tampilan dan tata letak baru telah diterbitkan.

Jurnal Sosial Ekonomi Kelautan dan Perikanan sesuai dengan Keputusan Lembaga IImu Pengetahuan Indonesia 329/E/2016 tertanggal 24 Maret 2016, telah Terakreditasi dengan Nomor Akreditasi: 741/AU3/P2MI-LIPI/04/2016.

Guna peningkatan nilai akreditasi di masa mendatang maka Jurnal Sosial Ekonomi Kelautan dan Perikanan Vol. 11 No. 2 Tahun 2016 telah mengalami perbaikan-perbaikan sesuai dengan saran dan petunjuk dari Tim Akreditasi Jurnal Pusat Dokumentasi IImiah Indonesia - Lembaga IImu Pengetahuan Indonesia (PDII LIPI).

Pada edisi kali ini, ditampilkan sepuluh karya tulis ilmiah yang meliputi; (i) Nilai Ekonomi Ekosistem Terumbu Karang di Kabupaten Wakatobi; (ii) Valuasi Ekonomi Ekosistem Mangrove di Wilayah Pesisir Kabupaten Merauke; (iii) Pengelolaan Perikanan Tangkap Berkelanjutan Waduk Cirata : Pendekatan Model Bio-Ekonomi Logistik; (iv) Potensi Sub-Sektor Perikanan Untuk Pengembangan Ekonomi di Bagian Selatan Gunungkidul; (v) Dampak Pemberlakuan Bea Keluar Terhadap Kinerja Ekspor Sektor Kelautan dan Perikanan Indonesia; (vi) Kapasitas Jaringan Sosial dan Kebijakan Revitalisasi Pelabuhan Perikanan Di Pulau Terdepan (Pelajaran dari Revitalisasi Pangkalan Pendaratan Ikan Lugu, di Kabupaten Simeulue); (vii) Diversifikasi Mata Pencaharian dan Pendapatan Rumah Tangga di Kawasan Pesisir Kabupaten Wakatobi, Sulawesi Tenggara; (viii) Peranan "Bantal Sosial" Pada Mata Pencaharian Nelayan Skala Kecil di Jawa; (ix) Struktur Pendapatan Perikanan Tangkap Keluarga Nelayan dan Implikasinya: Analisis Data Panel Kelautan dan Perikanan Nasional; (x) Kompetensi Nelayan Rawai Tuna Ditinjau dari Standar Kompetensi Kerja Nasional Indonesia (SKKNI) di Pelabuhan Perikanan Nusantara Palabuhanratu.

Dengan diterbitkannya jurnal ini, diharapkan dapat memberikan informasi hasil penelitian di bidang sosial ekonomi yang ada kepada masyarakat dan menambah wawasan ilmu pengetahuan di bidang sosial ekonomi kelautan dan perikanan bagi akademisi dan peneliti. Saran dan masukan dari pembaca sangat diharapkan guna kesempurnaan penerbitan jurnal di masa mendatang. 


\section{JURNAL SOSIAL EKONOMI KELAUTAN DAN PERIKANAN \\ Volume 11 Nomor 2, Tahun 2016}

DAFTAR ISI

KATA PENGANTAR

DAFTAR ISI

NILAI EKONOMI EKOSISTEM TERUMBU KARANG DI KABUPATEN WAKATOBI

Oleh : Andrian Ramadhan, Lindawati dan Nendah Kurniasari

VALUASI EKONOMI EKOSISTEM MANGROVE DI WILAYAH PESISIR KABUPATEN MERAUKE

Oleh : Maria M.D. Widiastuti, Novel Novri Ruata dan Taslim Arifin

PENGELOLAAN PERIKANAN TANGKAP BERKELANJUTAN WADUK CIRATA :

PENDEKATAN MODEL BIO-EKONOMI LOGISTIK

Oleh : Zuzy Anna

POTENSI SUB-SEKTOR PERIKANAN UNTUK PENGEMBANGAN EKONOMI DI BAGIAN SELATAN GUNUNGKIDUL

Oleh : Gilang Adinugroho

DAMPAK PEMBERLAKUAN BEA KELUAR TERHADAP KINERJA EKSPOR SEKTOR KELAUTAN DAN PERIKANAN INDONESIA

Oleh : Estu Sri Luhur dan Tajerin

KAPASITAS JARINGAN SOSIAL DAN KEBIJAKAN REVITALISASI PELABUHAN

PERIKANAN DI PULAU TERDEPAN (Pelajaran dari Revitalisasi Pangkalan

Pendaratan Ikan Lugu, di Kabupaten Simeulue)

Oleh : Armen Zulham

DIVERSIFIKASI MATA PENCAHARIAN DAN PENDAPATAN RUMAH TANGGA

DI KAWASAN PESISIR KABUPATEN WAKATOBI, SULAWESI TENGGARA

Oleh : Ngadi

PERANAN "BANTAL SOSIAL" PADA MATA PENCAHARIAN NELAYAN SKALA KECIL DI JAWA

Oleh : Budi Wardono dan Akhmad Fauzi

STRUKTUR PENDAPATAN PERIKANAN TANGKAP KELUARGA NELAYAN DAN IMPLIKASINYA: Analisis Data Panel Kelautan dan Perikanan Nasional

Oleh : Rikrik Rahadian, Maulana Firdaus dan Andrian Ramadhan
Halaman

i

ii

$133-146$

$147-159$

$161-172$

$173-183$

$185-200$

$201-208$

$209-223$

$225-235$

$237-249$ 
KOMPETENSI NELAYAN RAWAI TUNA DITINJAU DARI STANDAR KOMPETENSI

KERJA NASIONAL INDONESIA (SKKNI) DI PELABUHAN PERIKANAN NUSANTARA

PALABUHANRATU

Oleh : Yasinta Anugerah, Tri Wiji Nurani dan Muhammad Fedi A. Sondita 


\title{
INDEKS ABSTRAK JURNAL SOSIAL EKONOMI KELAUTAN DAN PERIKANAN (ABSTRACT INDEX OF JOURNAL SOCIO-ECONOMICS MARINE AND FISHERIES)
}

Vol. 11 No. 2, Desember 2016

\author{
NILAI EKONOMI EKOSISTEM TERUMBU KARANG DI KABUPATEN WAKATOBI \\ Economic Value of Coral Reef Ecosystem in the Wakatobi District \\ Andrian Ramadhan, Lindawati dan Nendah Kurniasari
}

\section{ABSTRAK}

Ekosistem terumbu karang memiliki fungsi ekologi dan ekonomi yang memberi manfaat barang dan jasa kepada manusia. Tidak hanya itu, interaksi yang terjadi antara sesama manusia didalam memanfaatkan ekosistem terumbu karang juga membentuk suatu nilai budaya. Penelitian ini bertujuan untuk mengestimasi nilai ekonomi dari barang dan jasa yang dihasilkan ekosistem terumbu karang termasuk nilai budaya. Penelitian dilakukan di Kabupaten Wakatobi pada tahun 2015. Data yang dikumpulkan berupa data primer dan data sekunder. Pemilihan responden dilakukan secara purposive sampling, dengan jumlah responden sebanyak 67 orang untuk penangkapan ikan dan 42 responden untuk pembudidaya rumput laut. Metode analisis data menggunakan pendekatan produktivitas atau effect on production. Hasil penelitian menunjukkan bahwa total nilai ekonomi yang dihasilkan dari barang dan jasa ekosistem terumbu karang di Wakatobi mencapai lebih dari 4 triliun rupiah atau setara dengan 163 juta rupiah per hektar per tahun. Nilai terbesar disumbang oleh nilai ekologi khususnya sebagai pelindung lingkungan pesisir yang mencapai lebih dari $79 \%$. Besarnya nilai ekologi menunjukkan pentingnya peranan ekosistem dimana rusaknya ekosistem berpotensi membebani negara dengan biaya yang sangat besar hanya untuk menjaga keberlanjutan lingkungan ekosistem pesisir di Wakatobi.

Kata Kunci: nilai ekonomi, ekosistem terumbu karang, wilayah pesisir, barang dan jasa, Wakatobi

\section{ABSTRACT}

Coral reef ecosystem has ecological and economical functions and enables to provide benefits in term of goods and services to human being. Furthermore, it also creates socio-cultural value from interaction among people in order to take the benefit of ecosystem. This study was conducted in Wakatobi in 2015. The purpose of this study is to estimate the economic value of the coral reef ecosystem functions both directly and indirectly. Data collected consist of primary and secondary data. Data were purposively sampled from 67 of fishers and 42 respondents of seaweed farmer. Results showed that the calculated total economic value of coral reefs in Wakatobi is accounted for more than 4 trillion rupiahs, in other word it was 163 million rupiahs per hectare per year. The largest value were come from ecological functions particularly from coastal protection function by which accounted for more than $79 \%$. This result indicates the important of ecosystem where in case of coral will be no longer existed, government should allocate a lot of money just to ensure the coastal environment sustainability in Wakatobi.

Keywords: economic value, coral reef, coastal area, goods and services, Wakatobi 


\section{VALUASI EKONOMI EKOSISTEM MANGROVE DI WILAYAH PESISIR KABUPATEN MERAUKE Economic Valuation of Mangrove Ecosystem in The Coastal of Merauke District}

Maria M.D. Widiastuti, Novel Novri Ruata dan Taslim Arifin

\begin{abstract}
ABSTRAK
Ekosistem mangrove mengalami tekanan dan penurunan jasa lingkungan diduga karena abrasi dan fenomena alam serta aktivitas masyarakat seperti penggalian pasir di pesisir pantai. Pemerintah telah melakukan upaya konservasi hutan mangrove dengan cara penanaman kembali, namun belum berhasil. Salah satu permasalahan adalah belum atau tidak adanya informasi nilai ekonomi mangrove sebagai dasar penentuan program konservasi. Penelitian ini bertujuan mengetahui nilai ekonomi ekosistem mangrove di pesisir Laut Arafura meliputi 3 distrik yaitu Malind, Merauke dan Naukenjerai. Metode yang digunakan yaitu TEV (Total Economic Value) yang terdiri dari analisis nilai guna langsung menggunakan harga pasar. Nilai guna tidak langsung dan nilai pilihan menggunakan benefit transfer. Nilai non guna yang terdiri dari nilai keberadaan dan nilai pewarisan menggunakan WTP (willingness to pay). Hasil penelitian menunjukkan bahwa nilai ekonomi hutan mangrove di kawasan pesisir pantai Laut Arafura per tahun sebesar Rp. 213.344.656.759,00 (213 Milyar Rupiah) atau setara dengan Rp. 21.075.240,00/ha/ tahun atau setara dengan Rp. 8,6 juta rupiah per kepala keluarga.
\end{abstract}

Kata Kunci: valuasi ekonomi, ekosistem mangrove, pesisir pantai Arafura

\section{ABSTRACT}

Mangrove ecosystem was under pressured and decreased environmental services allegedly because of abrasion and natural phenomena as well as community activities such as quarrying of sand on the coastal. The government has made mangrove forests conservation by replanting, but it has not succeeded. One of the problems is the lack or absence of the economic value information as a basis for determining mangrove conservation program. This study aims at determining the economic value of mangrove ecosystems in the Coastal of Arafura Sea covering three districts of Malind, Merauke and Naukenjerai. The method used is a TEV (Total Economic Value) consisting of direct use value analysis using market prices. Indirect use values and the option value using transfer benefit. Nonuse value which consists of the value of the existence and value of inheritance were using WTP (Willingness To Pay). Results showed that the economic value of mangrove forests in coastal area of Arafura Sea per year accounted for Rp. 213,344,656,759.00 (213 billion rupiah) or equivalent to Rp. 21,075,240.00/ha/year or equivalent to Rp. 8.6 million per household.

Keywords: economic valuation, ecosystem mangrove, Arafura coastal

\section{PENGELOLAAN PERIKANAN TANGKAP BERKELANJUTAN WADUK CIRATA: PENDEKATAN MODEL BIO-EKONOMI LOGISTIK \\ Sustainable Capture Fishery Management in The Cirata Reservoir: A Bio-Economic Modelling Approach}

Zuzy Anna

\section{ABSTRAK}

Perikanan tangkap di Waduk Cirata, merupakan salah satu potensi yang dapat diandalkan bagi pemenuhan kebutuhan hidup masyarakat sekitarnya, namun belum dikelola dengan baik. Faktanya kontribusi sektor perikanan tangkap waduk ini pada perekonomian daerah, masih rendah. Penelitian ini dilakukan untuk menganalisis pengaruh aktivitas produksi (penangkapan) terhadap kondisi sumber daya ikan seperti parameter biologi dan rente sumberdaya perikanan pada kondisi aktual, lestari, dan optimal, dengan menggunakan model bio-ekonomi standar logistik dan Gompertz. Skenario model yang digunakan adalah analisis bioekonomi model logistik Gordon Schaefer (GS) dengan

\section{ABSTRACT}

Capture fishery in the Cirata Reservoir is one of the potency that can be relied for the surrounding community subsistence, but it has not received propermanagement. In fact, it was poor contribution to the regional economy. This study aims to analyze the impact of production activities, on fish resources, such as biological parameters and fishery resource rents on actual conditions, sustainable, and optimally, by using bio-economic model of standard logistic and Gompertz. Modeling scenarios used a bioeconomic model of logistics Gordon Schaefer (GS) with the parameter estimation of Fox algorithm. Analysis of the fishery was carried out by using a scenario of open access management regime, Maximum Sustainable 
estimasi parameter algoritma Fox. Analisis perikanan tangkap dilakukan dengan menggunakan skenario rezim pengelolaan Open Access (OA), Maximum Sustainable Yield (MSY) dan Maximum Economic Yield (MEY). Hasil penelitian menunjukan adanya overfishing dan overcapacity pada 5 tahun (15 kuartal) pengamatan, yang ditandai dengan adanya kelebihan effort pada Model GS. Pengelolaan dengan menggunakan rezim MEY memberikan nilai rente yang paling maksimum, dengan biomass yang lebih konservatif, dan effort yang lebih efisien. Implikasi kebijakan pengelolaan perikanan tangkap di waduk melalui rasionalisasi jumlah alat tangkap. Model MSY mengisyaratkan rasionalisasi alat tangkap lebih sedikit dibandingkan model MEY. Alternatif pembatasan output atau kuota output juga dapat dilakukan dengan menggunakan nilai JTB.

$\begin{aligned} \text { Kata Kunci: } & \text { perikanan tangkap, Waduk } \\ & \text { Cirata, pengelolaan berkelanjutan, } \\ & \text { model bioekonomi, Gordon } \\ & \text { Schaefer, model estimasi parameter } \\ & \text { fox, rasionalisasi }\end{aligned}$

Yield (MSY) and the Maximum Economic Yield (MEY). Results showed overfishing and overcapacity of the fishery in 5 years of observation (quarterly), which was characterized by an excess of effort in the GS model. Management using MEY regime provides the maximum possible value of rents, with biomass more conservative and more efficient effort. Policy implications reveal from the study is reservoir management through rationalized number of fishing gear or boats. MSY model suggests rationalization of fishing gear less than the model MEY. Alternative output restrictions or quotas outputs can also be implemented by using the value of total allowable catch.
Keywords: capture fishery, Cirata Reservoir, sustainable management, bioeconomic model, Gordon Schaefer model, parameter estimates of FOX model, rationalization

\title{
POTENSI SUB-SEKTOR PERIKANAN UNTUK PENGEMBANGAN EKONOMI DI BAGIAN SELATAN GUNUNGKIDUL
}

\section{Fisheries Sub-Sebctor Potential For Economic Development in The South of Gunungkidul}

\author{
Gilang Adinugroho
}

\section{ABSTRAK}

Pembangunan di bagian selatan Gunungkidul masih tertinggal dibandingkan daerah lain. Pada tahun 2014 nilai produksi perikanan laut di bagian selatan mencapai 29 milyar, menjadi potensi mengembangkan ekonomi wilayah. Penelitian ini bertujuan penelitian untuk: (1) mengidentifikasi perkembangan kegiatan perikanan laut, dan; (2) mengidentifikasi peran dan potensi sub sektor terhadap ekonomi wilayah di bagian Selatan Gunungkidul. Metode penelitian deskriptif kualitatif dan lokasi berada di 6 kecamatan di bagian selatan yaitu Panggang, Purwosari, Tepus, Saptosari, Tepus, dan Girisubo. Produksi perikanan laut di bagian selatan selama 2004-2013 mengalami peningkatan sedangkan nilai produksinya relatif fluktuatif. Komoditas utamanya adalah teri, tuna, cakalang dan pari. Terdapat 8 PPI di Gunungkidul, Sadeng mempunyai produksi tertinggi dan fasilitas paling lengkap. Kontribusi sub sektor perikanan kecamatan bagian selatan terhadap kabupaten terus menurun selama 2004-2013. Hampir semua sub sektor perikanan di bagian selatan merupakan sektor unggulan, kecuali di Purwosari. Hasil analisis menunjukkan bahwa kegiatan perikanan di Tepus merupakan unggulan dan prospektif. Sub sektor perikanan di Saptosari, Tanjungsari, Panggang dan Girisubo termasuk unggulan tapi tidak prospektif. Kegiatan perikanan di Purwosari bukan sektor unggulan dan tidak prospektif.

Kata Kunci: perikanan, ekonomi wilayah, prospektif

\section{ABSTRACT}

South Gunung Kidul is still undeveloped among other regions. Marine fisheries were production value in the southem reached IDR 29 billion in 2014, become regional economic development potential. The objectives of 1) research identifies the role and also development status of marine fisheries and 2) may identifies the role and also fisheries sub-sector potencies for the southern Gunung Kidul economic region. Research used qualitative descriptive with 6 locations at Panggang, Purwosari, Tepus, Saptosari, Tepus, and Girisubo. Fisheries production had increased during 2004-2013 but value production was fluctuated were anchovy, tuna, skipjack and rays as with commodities. There were 8 fisheries ports in Gunung Kidul with Sadeng had the highest production which the most also facilities. Almost all fisheries activities in the southern became leading sectors in regional economic, but Purwosari. The results had showed that fishing activities in Tepus were eminent and prospective. However, fisheries in Saptosari,Tanjungsari, Panggang and Girisubo were eminent seeded but not prospective, while were eminent Purwosari wasn't eminent and also not prospective.

Keywords: fisheries, regional economic, prospective 


\title{
DAMPAK PEMBERLAKUAN BEA KELUAR TERHADAP KINERJA EKSPOR SEKTOR KELAUTAN DAN PERIKANAN INDONESIA \\ Impacts of Export Duties on Its Performance of The Marine and Fisheries Sector
}

\author{
Estu Sri Luhur dan Tajerin
}

\begin{abstract}
ABSTRAK
Tulisan ini bertujuan untuk menganalisis dampak pemberlakuan bea keluar terhadap produk primer perikanan terhadap kinerja ekspor sektor kelautan dan perikanan sebagai salah satu cara mengatasi permasalahan tersebut. Kajian ini menggunakan data sekunder dengan mengambil Tabel I-O tahun 2008 yang kemudian disusun dalam bentuk Computable General Equilibrium (CGE) dengan menggunakan model Orani-G. Komoditas yang dianalisis adalah ikan Tuna Tongkol Cakalang (TTC), ikan tangkap lainnya, patin, kerapu, rumput laut, budidaya lainnya, udang, ikan kering dan ikan olahan. Kajian ini dilakukan dengan menggunakan simulasi tiga skenario pemberlakuan bea keluar, yaitu 7,5\% (sim-1), 15\% (sim-2), dan 22,5\% (sim-3). Hasil kajian menunjukkan bahwa skenario 3, yaitu pemberlakuan tarif bea keluar $22,5 \%$ memberikan dampak terbesar terhadap kinerja makro ekonomi diantaranya peningkatan GDP $0,01 \%$ dan konsumsi rumah tangga sebesar 0,046\%. Dampak terhadap kinerja sektoral: (1) output dan nilai tambah produk primer perikanan mengalami penurunan terbesar pada ikan TTC sebesar $0,68 \%$, sedangkan output dan nilai tambah produk olahan perikanan mengalami peningkatan terbesar pada ikan olahan sebesar 0,72\%; (2) ekspor produk primer perikanan mengalami penurunan terbesar pada udang sebesar $35,81 \%$, sedangkan ekspor produk olahan perikanan mengalami peningkatan terbesar pada ikan olahan sebesar $2,41 \%$, dan; (3) impor produk primer perikanan produk olahan perikanan mengalami penurunan terbesar pada udang sebesar 23,09\%. Implikasi kebijakannya adalah pemerintah dapat lebih meningkatkan ekspor melalui pengenaan bea keluar ini. Kebijakan tersebut harus dilakukan hati-hati dengan memperhatikan perubahan ekonomi di negara importir dan di dunia.
\end{abstract}

Kata Kunci: bea keluar, nilai tambah, ekspor, CGE, kelautan dan perikanan

\section{ABSTRACT}

This paper aimed at analyzing the impact of export duties imposed on fishery primary products toward export performance of marine and fisheries in order to answer the issue. This study used input output table 2008 which is arranged in Computable General Equilibrium (CGE) form using Orani-G model. Commodities concerned were Tuna, Mackarel Tuna, Skipjack Tuna (TTC), catfish, grouper, seaweed, shrimp, dried fish, processed fish, other cached fishes and other aquaculture products. This study carried out with three scenarios of export duties, i.e. 7.5\% (sim-1), 15\% (sim-2), and 22.5\% (sim-3). Results showed that $22,5 \%$ of export duties would give higher macro economic performance where GDP increase at $0.01 \%$ and household consumption increase at $0.046 \%$. Impact on sectoral performance were: (1) output and value added of primary fishery products experienced largest decline in TTC by $0.68 \%$, while the output and value added of processed fishery products experienced largest increase in processed fish by $0.72 \%$; (2) export of primary fishery products experienced largest decline in shrimp by $35.81 \%$, while exports of processed fishery products experienced largest increase in fish processed by $2.41 \%$, and ; (3) imports of primary products for processed fishery products experienced largest decline in shrimp by $23.09 \%$. Policy implication should be taken by the government was to increase the number of export products with imposing export duties. The imposed policies should be carefully handled and considered world economic changes, particularly to the targeting countries.

Keywords: export duties, value added, export, CGE, marine and fisheries 


\section{KAPASITAS JARINGAN SOSIAL DAN KEBIJAKAN REVITALISASI PELABUHAN PERIKANAN DI PULAU TERDEPAN (Pelajaran Dari Revitalisasi Pangkalan Pendaratan Ikan Lugu, di Kabupaten Simeulue)

\author{
Social Networking Capacity and The Policy of Revitalization of Fishing Port in Frontier Island \\ (A Lesson From Revitalization of Lugu Fishing Port, in Simeulue Regency)
}

\section{Armen Zulham}

\section{ABSTRAK}

Pembangunan ekonomi pulau terdepan melalui program Sentra Kelautan dan Perikanan Terpadu (SKPT) sedang giat dilakukan. Program ini merupakan kegiatan andalan Kabupaten Simeulue dalam bentuk kegiatan renovasi pabrik es, air blast freezer, docking kapal serta membangun pertokoan dan perkantoran pada Pangkalan Pendaratan Ikan (PPI) Lugu. Pembangunan infrastruktur tersebut diharapkan mendorong berkembangnya bisnis perikanan, memfungsikan (revitalisasi) PPI Lugu, dan meningkatkan kontribusi Lapangan Usaha Perikanan pada PDRB Kabupaten Simeulue. Tujuan tulisan ini adalah mempelajari jaringan sosial dan mencari strategi revitalisasi (memfungsikan) PPI Lugu Pengamatan lapangan untuk tujuan revitalisasi PPI Lugu, dilakukan melalui survei cepat pada Januari 2015 dan wawancara mendalam terhadap 30 responden nelayan dan 3 responden "toke bangku" tentang aspek sosial ekonomi dan bisnis perikanan pada April 2016. Data di analisis secara deskriptif dan berdasarkan teori ekonomi mengacu teori Henderson and Quant dan teori sosiologi ekonomi mengacu teori Damsar dan Indrayani. Hasil penelitian ini menunjukkan peran dan kapasiatas pelaku bisnis, jaringan sosial, pertukaran sosial pada bisnis perikanan di Simeulue tidak dijadikan dasar dalam menyusun kebijakan merevitalisasi PPI Lugu. Hal ini menyebabkan, sampai bulan Agustus 2016 PPI belum berfungsi. Tulisan ini merekomendasikan, operasional PPI Lugu, dilakukan dalam dua tahap: jangka pendek dengan memberi konsesi pada perusahaan/ pengusaha yang memiliki modal dan jaringan pasar yang luas untuk mengelola Cold Storage dan ABF atau Pabrik es. Jangka panjang mulai tahun ketiga operasional PPI Lugu dilaksanakan dengan struktur kelembagaan pelabuhan perikanan yang berlaku.

Kata Kunci: pangkalan pendaratan ikan, nelayan, jaringan sosial, transaksi sosial, Simeulue

\section{ABSTRACT}

The economic development of frontier islands through the Integrated Marine and Fisheries Development Program (SKPT) is intensively being carried out. This program is the main activity of Simeulue Regency by renovation of the cold storage, ice factory, air blast freezer, ship dock as well as building market and offices in the Lugu Fishing Port. The development of infrastructures is expected to encourage the growth of fisheries business, function (revitalization) of the Lugu Fishing Port, and increase the contribution of fisheries business field in the gross regional domestic product of Simeulue. The aim of this report is to understand social network and to find the strategy of the Lugu Fishing Port revitalization, field observation for the Lugu Fishing Port revitalization was conducted by a quick survey in January 2015 and deep interview about socio economic aspect and fisheries business was conducted on 30 fishers and 3 fish traders (toke bangku) in April 2016. Data was analyzed descriptive based on economic theory of Handerson and Quant and the sociologyeconomy theory of Damsar and Indrayani. Results of this study showed that role and capacity of business, social network, and social exchange in fisheries business in Simeulue not used as a references in arranging the policy of the Lugu Fishing Port revitalization. As a result, the fishing port has not functioned until August 2016. This study recommends the operational of the Lugu Fishing Port to be conducted in two steps: short-term in giving concession to companies/businessman having the fund and wide market network to manage cold storage or ice factory, and long term starting from the third year by operating the fishing port based on the fishing port organizational structure applied.

Keywords: fishing port, fisher's, social networking, social transaction, Simeulue 


\title{
DIVERSIFIKASI MATA PENCAHARIAN DAN PENDAPATAN RUMAH TANGGA DI KAWASAN PESISIR KABUPATEN WAKATOBI, SULAWESI TENGGARA
}

\section{Household Livelihood Diversification and Income in Coastal Area of Wakatobi District, Southeast Sulawesi}

\section{Ngadi}

\section{ABSTRAK}

Salah satu persoalan mendasar penduduk Kabupaten Wakatobi adalah keterbatasan akses sumber mata pencaharian yang berimplikasi terhadap rendahnya pendapatan rumah tangga. Paper ini bertujuan untuk membahas mata pencaharian dan pendapatan rumah tangga di kawasan pesisir Kabupaten Wakatobi tahun 2015. Penelitian dilakukan di tiga desa pesisir Kabupaten Wakatobi dengan survei, wawancara terbuka dan penelusuran data sekunder. Analisis data dilakukan secara deskriptif. Hasil penelitian menunjukkan sebagian besar penduduk di Sombano bekerja sebagai petani rumput laut, sedangkan penduduk di Desa Longa dan Desa Waelumu bekerja di pertanian tanaman pangan dan perikanan tangkap. Sementara itu, ratarata pendapatan rumah tangga di pesisir Kabupaten Wakatobi termasuk rendah, terutama pada waktu musim gelombang kuat. Rumah tangga di Desa Waelumu memiliki rata-rata pendapatan rumah tangga tertinggi, sedangkan pendapatan terendah terdapat di Desa Longa. Rendahnya pendapatan nelayan di Wakatobi disebabkan praktek penangkapan ikan yang tidak ramah lingkungan, sehingga pemerintah perlu meningkatkan pengawasan dan kesadaran masyarakat. Di sisi lain, peningkatan produktivitas rumput laut dapat dilakukan melalui pengembangan bibit unggul dan pemberantasan penyakit.

Kata Kunci: mata pencaharian, pendapatan rumah tangga, kawasan pesisir, Kabupaten Wakatobi

\section{ABSTRACT}

One of the fundamental problems in Wakatobi District people is the limited access to livelihood sources that resulted on low household income. This paper discussed household livelihood in Wakatobi District coastal areas. The study was conducted in three villages of Wakatobi District coastal areas using survey, interviewed and secondary data collection. Data were analyzed descriptively. Result showed that majority of Sombano people worked as seaweed farmers, while Longa and Waelumu worked in crop farming and capture fisheries, respectively average household income in Wakatobi coastal areas was low, notably at the high wave season. Waelumu people had the highest average income, while the lowest was Longa. Relatively low fisher's income in Wakatobi was due to the practice of unfriendly fishing metode, therefore government has to push enforcement and public awareness. Moreover, seaweed productivity increasing could be achieved through development seeds quality development and also disease eradication.

Keywords: livelihood, household income, coastal areas, Wakatobi Regency

\section{PERANAN “BANTAL SOSIAL" PADA MATA PENCAHARIAN NELAYAN SKALA KECIL DI JAWA}

The Role "Social Cushion" on The Livelihood of Small Scale Fishers In Java

\author{
Budi Wardono dan Akhmad Fauzi
}

\begin{abstract}
ABSTRAK
Salah satu alasan yang kuat nelayan tangkap skala kecil tetap melaut meskipun mempunyai risiko tinggi karena peluang/prospek pendapatan/penerimaan yang tinggi pada satu saat. Risiko melaut tidak hanya membuat ketidakpastian tetapi juga karena risiko biaya operasional yang tinggi. Dihadapkan dengan kondisi biaya operasional yang tinggi, nelayan menggunakan strategi yang berbeda, salah satunya melekat pada peran tengkulak. Dalam pandangan konvensional, pedagang perantara/ langgan sebagai hambatan bagi nelayan
\end{abstract}

\section{ABSTRACT}

The expectation of high income is the most dominant factor to keep fishing by fisher despite its high risk. Uncertainty not only creates high risk situation but also operational cost. To cope with these situation, fisher creates alternatives strategy where one is having a relation with a middleman. In conventional views, middleman is perceived as a problem for fisher to have a competitive market for their product. Yet in developing country such as Indonesia, they play crucial role as a "social cushion" for small scale fisher's livelihood. This 
untuk menjadi kompetitif di pasar. Namun di negara berkembang seperti Indonesia, mereka memainkan peran penting sebagai "bantal sosial" dalam kehidupan nelayan skala kecil. Tujuan penelitian adalah menyelidiki tingkat kecenderungan keterikatan hubungan langgan/ pedagang antara sebagai "bantal sosial" dengan nelayan di dua daerah penangkapan ikan yang menonjol di pantai utara dan pantai selatan Jawa. Analisis data dilakukan dengan metode analisis kuantitatif yaitu model analisis multinomial logistik. Hasil penelitian menunjukkan bahwa nelayan dari pantai utara cenderung sangat kuat hubungannya dengan perantara untuk kelangsungan hidupnya dibandingkan dengan nelayan di pantai selatan. Implikasi dari temuan tersebut bahwa peran sentral langgan/perantara/tengkulak/langgan merupakan bentuk hubungan yang bersifat ekonomi dimana kedua belah pihak bisa mengambil keuntungan. Pola hubungan bukan hanya sekedar sebagai penyangga, namun lebih dari itu yaitu berfungsi sebagai "bantal" sosial (social cushion) para nelayan. Hubungan seperti ini merupakan bentuk layanan dimana para nelayan bisa mendapatkan alternatif layanan jasa "kredit" dari para perantara/ langgan/tengkulak. Bentuk layanan seperti yang diperankan oleh langgan/pedagang perantara selama ini belum bisa digantikan oleh lembaga pemerintah yang resmi, dimana pola hubungan tersebut sangat dibutuhkan oleh nelayan skala kecil. Pola hubungan tersebut selain dipengaruhi oleh lokasi, juga dipengaruhi oleh status kepemilikan kapal, lama kepemilikan kapal dan jumlah ABK.

Kata Kunci: mata pencaharian, tengkulak, nelayan skala kecil, resiko, "bantal sosial" research aims to investigate the level of relationship between middleman and fisher in two dominant area of northern and southern coast of Java. Data were analyzed using multinomial logistic analysis model. Results show the fisher dependency to middleman of northern coast java is higher than southern coast java. This relationship form is a mutual benefit where both fisher and middleman have advantages from this bond. Middleman's role is more than a buffer but more likely a "social cushion". Fisher could have a credit service from them that could not be served by government agencies. In the field, this kind of relationship is affected by the status, longest vessel ownership and so the number of the crew.

Keywords: livelihood, middlemen, small-scale fishers, risk, "social cushion"

\section{STRUKTUR PENDAPATAN PERIKANAN TANGKAP KELUARGA NELAYAN DAN IMPLIKASINYA: Analisis Data Panel Kelautan dan Perikanan Nasional Structure of Capture Fisheries Income Family Fisherman and Implications: Panel Data Analysis of The National Marine and Fishery}

Rikrik Rahadian, Maulana Firdaus dan Andrian Ramadhan

\section{ABSTRAK}

Kemiskinan merupakan sebuah kata yang sangat melekat dengan keluarga Nelayan, sehingga banyak usaha telah dilakukan oleh pemerintah untuk menanganinya, umumnya melalui pemberian bantuan serta pemberdayaan usaha keluarga nelayan. Penelitian ini dilakukan untuk melihat kondisi struktur pendapatan perikanan keluarga Nelayan selama ini melalui analisis ketergantungan pendapatan perikanan keluarga Nelayan terhadap tingkat usaha penangkapan. Analisis dilakukan dengan menggunakan analisis data Panel, dengan dua variabel berupa data rata-rata pendapatan keluarga Nelayan dan rata-rata pengeluaran BBM di enam lokasi tipologi penangkapan pada penelitian

\section{ABSTRACT}

Poverty is a word closely associated with fisher's households, thus far numerous government efforts such as grants and empowerment programs - have been conducted to tackle this problem. This paper is aimed at scrutinizing the income structure of fisher's households by analyzing the dependency of their income to their Catch Effort. The panel data analysis conducted based on the average Household's Fisheries Income and its average Gasoline Expenditure data of six PANELKANAS' Captured Fisheries locations-Bitung, Sampang, Sambas, Sibolga, Ogan Komering Ilir (OKI) and Purwakarta - which were observed through out the 2010-2013 periods. Results showed several phenomena, such as: (1). Catch effort is a significant factor positively affecting the household's fisheries income, as much as 15\% 
PANELKANAS - Bitung, Sampang, Sambas, Sibolga, OKI dan Purwakarta - sepanjang periode 2010-2013. Hasil analisis data sepanjang periode pengamatan menunjukkan beberapa fenomena berikut ini: (1). Peningkatan usaha penangkapan berpengaruh signifikan meningkatkan Pendapatan Perikanan Keluarga sebesar $15 \%$ dari nilai usaha yang dilakukan; (2). Terjadi rata-rata pendapatan perikanan non-penangkapan yang positif di semua lokasi penelitian; dan (3). Terdapat kesenjangan nilai rata-rata pendapatan perikanan non-perikanan antar lokasi penelitian. Berdasarkan hasil yang diperoleh, maka untuk membantu keluarga nelayan meningkatkan kesejahteraannya akan diperlukan kebijakan yang dapat mendorong peningkatan usaha penangkapan dan diversifikasi usaha perikanan.

Kata Kunci: tingkat usaha penangkapan, perikanan tangkap, pendapatan perikanan keluarga nelayan, analisis data panel of the total effort value; (2). There has been a positive average non-captured fisheries income in every location observed; and (3). There have been disparities of the average non-captured fisheries income among different locations. With such results, poverty alleviation of fisher's households would still require both catch-effort enhancing as well as livelihood diversifying policies.

Keywords: catching effort level, capture fisheries, fisheries household income, panel data analysis

\title{
KOMPETENSI NELAYAN RAWAI TUNA DITINJAU DARI STANDAR KOMPETENSI KERJA NASIONAL INDONESIA (SKKNI) DI PELABUHAN PERIKANAN NUSANTARA PALABUHANRATU \\ Competency of Tuna Longline Fishers Viewed From The Indonesian National Occupational Competency Standards in Palabuhanratu Nusantara Fishing Port
}

\author{
Yasinta Anugerah, Tri Wiji Nurani dan Muhammad Fedi A. Sondita
}

\section{ABSTRAK}

Nelayan harus memiliki kompetensi saat melakukan pekerjaan kasar di lingkungan kapal dan pendaratan tuna harus memiliki kualitas tertentu. Standar Kompetensi Kerja Nasional (SKKNI) untuk nelayan rawai tuna dapat menjadi suatu pendekatan untuk mengetahui kompetensi nelayan tanpa adanya latar belakang pendidikan formal yang tinggi. Penelitian ini dilakukan untuk menentukan tingkat kompetensi nelayan rawai tuna di PPN Palabuhanratu dengan mengacu pada standar tertentu. Pengambilan data dilakukan pada bulan Desember 2014 - Februari 2015. Data kompetensi dari 25 nelayan dengan 5-10 tahun pengalaman kerja dikumpulkan melalui pengamatan langsung, wawancara dengan nelayan dan pengawas di pelabuhan. Data yang dimaksud adalah ukuran terpenuhinya kriteria kinerja yang ditetapkan dalam standar. Nakhoda menunjukan kesesuaian tertinggi pada standar unit kompetensi Penangkapan ikan di laut dengan menggunakan rawai tuna, sedangkan ABK menunjukan kesesuaian tertinggi pada standar unit kompetensi Melakukan perawatan alat penangkap ikan berbahan utama tali dan pancing di laut. Kapten dan ABK menunjukkan tercapainya kompetensi lebih dari $50 \%$ dari standar.

Kata Kunci: nelayan, kompetensi, rawai tuna, SKKNI

\section{ABSTRACT}

Fishers must have a set of competence while doing menial jobs in the tuna boats and landings must have certain qualities. The Indonesian National Occupational Competency Standards (SKKNI) for tuna longline can be used to determine the status of competency of a fisher, without a high formal education background. This study was conducted to determine level competency of tuna longline fishers in PPN Palabuhanratu with reference to the given standards. Data collection was conducted in December 2014 - February 2015. Data on competency of 25 fishers with 5-10 year working experience were collected through direct observation, interviews with fishers and their supervisors at the fishing port. Data were measured in terms of the fulfillment performance criteria specified in the standard. The captains exhibited the highest compliance on standard competency unit of tuna longline capture while the crews exhibited the highest compliance on standard competency unit of hook and line fishing gear maintenance and protection at sea. The captains and crews indicated of more than $50 \%$ compliance achievement of the recommended standards.

Keywords: fishers, competency, tuna longline, SKKNI 


\section{(Indeks Pengarang)}

(Author Index)

Adinugroho, Gilang

$173-183$

Anna, Zuzy

$161-172$

Anugerah, Yasinta

$251-265$

Arifin, Taslim

$147-159$

Fauzi, Akhmad

225 - 235

Firdaus, Maulana

$237-249$

Kurniasari, Nendah

$133-146$

Lindawati

$133-146$

Luhur, Estu Sri

$185-200$

Ngadi

209 - 223

Nurani, Tri Wiji

$251-265$

Rahadian, Rikrik

$237-249$

Ramadhan, Andrian

$133-146$,

$237-249$

Ruata, Novel Novri

$147-159$

Sondita, Muhammad Fedi A.

$251-265$

Tajerin

$185-200$

Wardono, Budi

$225-235$

Widiastuti, Maria M. D.

$147-159$

Zulham, Armen

$201-208$ 


\section{(Indeks Subjek) \\ (Index Subject)}

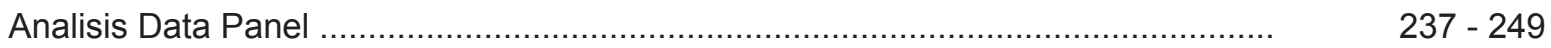

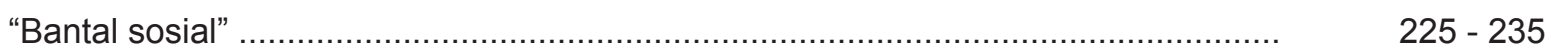

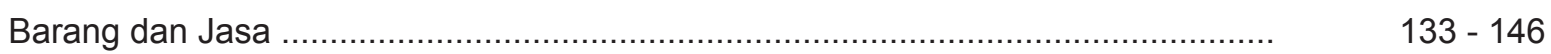

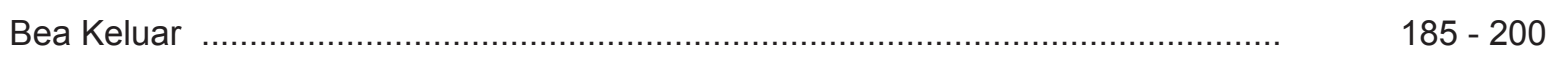

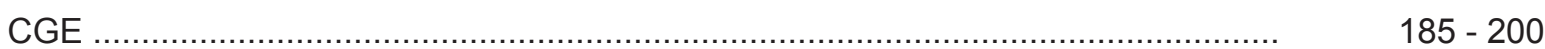

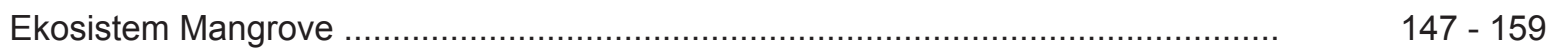

Ekosistem Terumbu Karang ......................................................................... $133-146$

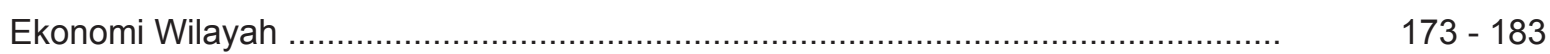

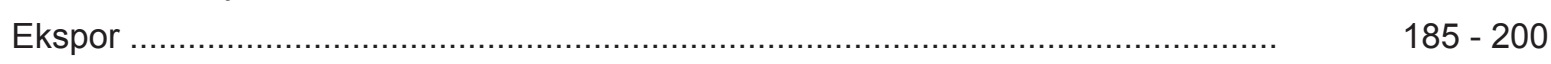

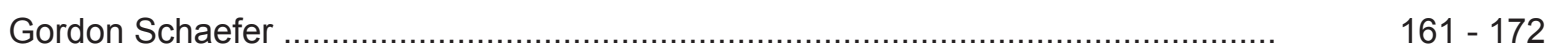

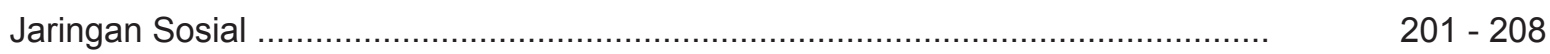

Kawasan Pesisir ........................................................................................ $209-223$

Kabupaten Wakatobi ............................................................................... 209 - 223

Kelautan dan Perikanan ......................................................................... $185-200$

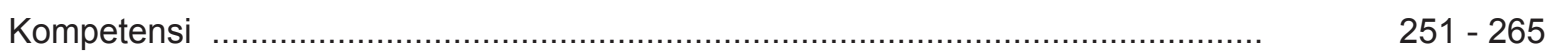

Mata pencaharian …......................................................................... $209-223$

$225-233$

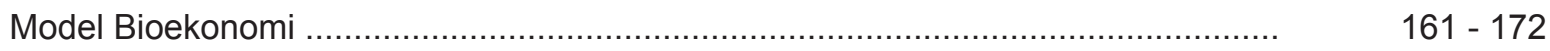

Model Estimasi Parameter Fox ............................................................... $161-172$

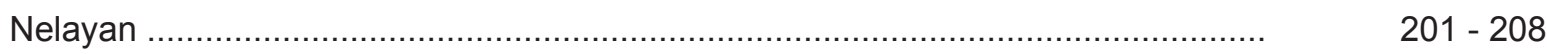

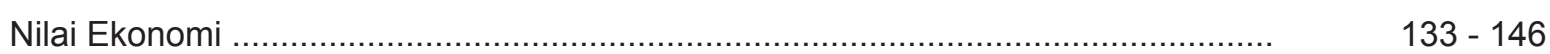

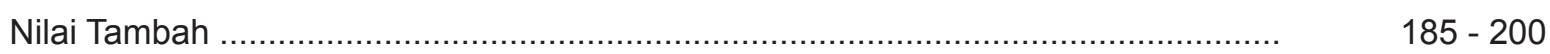

Pangkalan Pendaratan Ikan ....................................................................... $201-208$

Pendapatan Perikanan Keluarga Nelayan ....................................................... $\quad 237$ - 249

Pendapatan Rumah Tangga ....................................................................... $209-223$

Pengelolaan Keberlanjutan .................................................................. $161-173$

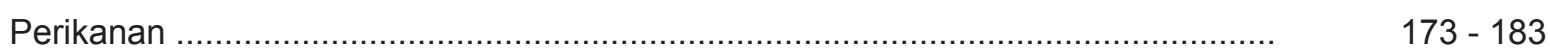

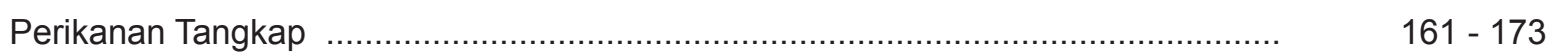

$237-249$

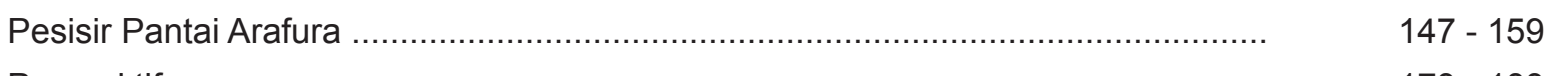

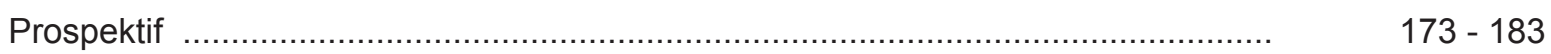

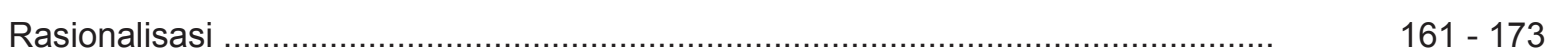

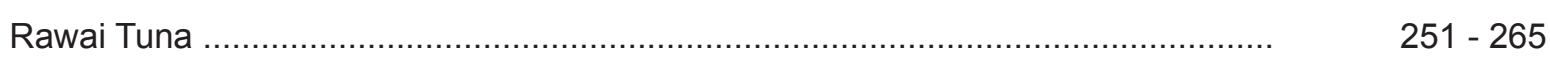

Resiko ............................................................................... 225 - 235

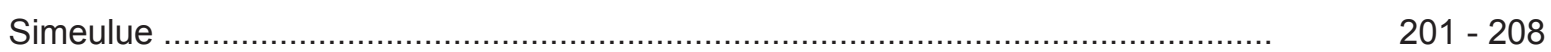

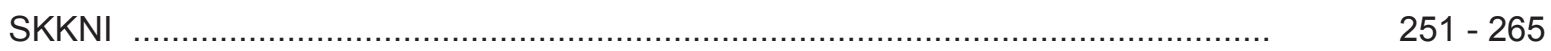

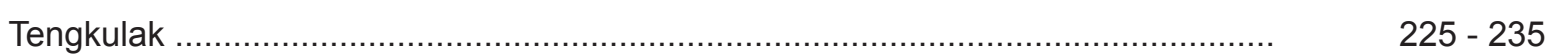

Tingkat Usaha Penangkapan ................................................................. 237 - 249 
Transaksi Sosial

$201-208$

Valuasi Ekonomi

$147-159$

Waduk Cirata

$161-172$

Wakatobi

$133-146$

Wilayah Pesisir

$133-146$ 


\section{JURNAL SOSIAL EKONOMI KELAUTAN DAN PERIKANAN \\ Pedoman Bagi Penulis}

Jurnal Sosial Ekonomi Kelautan dan Perikanan memuat hasil-hasil penelitian yang berkaitan dengan penelitian bidang sosial dan ekonomi kelautan dan perikanan. Naskah yang diterima yaitu karya tulis yang merupakan karya asli dan belum pernah diterbitkan dipublikasi lainnya.

\section{UMUM}

Kertas : HVS A4 $(21,0 \times 29,7 \mathrm{~cm})$

Margin : Kiri $3 \mathrm{~cm}$

Bawah, Kanan dan Atas $2 \mathrm{~cm}$

Huruf : Arial, 11 pt, hitam, 1,5 spasi. ketik dalam Bahasa Indonesia (kecuali abstrak) atau Bahasa Inggris yang baik dan benar, tidak diperkenankan menggunakan singkatan yang tidak umum.

Struktur : Judul, Abstrak, Pendahuluan, Metodologi, Hasil dan Pembahasan, Kesimpulan dan Implikasi Kebijakan, Ucapan Terima Kasih dan Daftar Pustaka

Naskah dikirim melalui Online di alamat web http://ejournal-balitbang.kkp.go.id index.php/sosek atau alamat ke Redaksi Pelaksana Jurnal Sosial Ekonomi Kelautan dan Perikanan, Gedung Balitbang KP I, Komplek Bina Samudera, JI. Pasir Putih I Ancol Timur, Jakarta 14430, telp (021) 64700924, fax (021) 64711583, Email: pt.sosek@gmail.com

\section{PENULISAN NASKAH}

Naskah ditulis rapi dengan panjang naskah maksimum 20 halaman (termasuk gambar dan tabel) dan setiap lembar tulisan diberi nomor halaman.

\section{Judul}

Judul harus ditulis secara ringkas (maksimal 15 kata), tetapi cukup informatif untuk menggambarkan isi tulisan. Ditulis dalam Bahasa Indonesia dan di bawahnya dalam Bahasa Inggris, menggunakan huruf Arial, kapital Bold, 12 pt, center.

\section{Penulis dan institusi}

Penulis dan Institusinya ditulis berurutan di bawah judul. Nama penulis ditulis dengan huruf Arial, kapital bold, $10 \mathrm{pt}$, center. Institusi asal (alamat, nomor telepon, nomor faksimil, serta e-mail) ditulis dengan huruf Arial, kapital dan kecil, 10 pt, center.

\section{Abstrak}

Ditulis dalam bahasa Indonesia dan bahasa Inggris, tidak lebih dari 200 kata dan hanya satu kalimat/ paragraf. Abstrak memberikan informasi singkat namun jelas tentang alasan penelitian dilakukan, tujuan yang ingin dicapai, metode yang digunakan, hasil yang diperoleh serta kesimpulan. ditulis dengan huruf Arial, 10 pt.

\section{Kata Kunci}

Ditulis dalam Bahasa Indonesia dan Inggris, terdiri dari 4 sampai 6 kata tulis di bawah abstrak.

\section{Pendahuluan}

Pendahuluan sebaiknya dimulai dengan menjelaskan latar belakang penelitian, perumusan masalah, kerangka teoritis, dan tujuan penelitian yang dibuat secara ringkas. 


\section{Metodologi}

Diuraikan secara rinci dan jelas mengenai lokasi dan waktu penelitian, bagaimana data diperoleh dan sumbernya serta bagaimana metode analisis datanya, jika metode yang digunakan telah diketahui sebelumnya harus dicantumkan acuannya.

\section{Hasil dan Pembahasan}

Bagian ini menyuguhkan data dan informasi yang ditemukan peneliti serta dipakai sebagai dasar penyimpulan bahkan penyusunan teori baru. Secara umum disuguhkan secara bertahap dalam tiga bagian: uraian temuan data dan informasi yang terkumpul. Sertakan data pendukung yang berupa tabel, grafik dan gambar seperlunya untuk memperjelas dan mempersingkat uraian yang harus diberikan.

\section{Kesimpulan dan Implikasi Kebijakan}

Kesimpulan diuraikan secara ringkas dan jelas mengacu pada pokok-pokok bahasan serta kemampuan mengartikulasikan temuan pokok untuk rekomendasi kebijakan, ditulis secara singkat dan jelas dalam dua atau tiga kalimat Pada intinya menegaskan apakah tujuan penelitian ini sudah tercapai atau masih ada hal-hal yang belum dicapai. Bila belum, jelaskan apa penyebabnya.

\section{Ucapan Terima Kasish}

Ucapan Terima Kasih Ditulis dengan formal, ucapan diberikan pihak tertentu, misalnya Sponsor penelitian, nama yang benar-benar terlibat dalam pelaksanaan penelitian dan ucapan tidak terlalu berlebihan.

\section{Daftar Pustaka}

Dicantumkan dalam naskah bila ada pengutipan dari sumber lain. Proporsi daftar pustaka yang diacu yaitu $80 \%$ merupakan rujukan primer dan merupakan terbitan 5 tahun terakhir. Tuliskan hanya pustaka yang dirujuk dalam makalah saja. Hindari pustaka yang bersumber pada majalah, koran, atau media lainnya yang non-ilmiah. Disusun berdasarkan abjad.

\section{Buku :}

Huda, H.M., R.A. Wijaya dan S. Koeshendrajana. 2011. Dinamika Perkembangan Sosial Ekonomi Usaha Rumah Tangga Petambak Garam. In Koeshendrajana (eds.), PANELKANAS: Dinamika Perkembangan Usaha, Pendapatan dan Konsumsi Rumah Tangga. Badan Riset Kelautan dan Perikanan. Jakarta

\section{Prosiding :}

Solihin, A., S. Koeshendrajana dan F. Y. Arthatiani. 2012. Harmonisasi Hukum Internasional Dalam Pemberantasan IUU Fishing dan Implementasinya dalam Peraturan Perundang-undangan Indonesia. In Isnansetyo et al. (eds.), Prosiding Seminar Nasional IX Tahun 2012., SE-04: 1-17. Jurusan Perikanan Fakultas Pertanian UGM. Yogyakarta.

\section{Jurnal IImiah :}

Pitcher, T.J. and D.B Preikshot. 2001. Rapfish: A Rapid Appraisal Technique to Evaluate the Sustainability Status of Fisheries. Fisheries Research. Vol 49(3): 255-270

\section{Artikel dari situs internet ;}

Sahyuti. 2012. Ciri-ciri Masyarakat Adat. http://syahyutivariabel.blogspot.com/2012/07/ciri-ciri-masyarakat-adat.html. (diakses 27 Desember 2012). 


\section{Laporan :}

Koeshendrajana, S., F. N. Priyatna, I. Mulyawan, A. Ramadhan, E. Reswati, R. Triyanti, A. Fahrudin, E. S. Kartamihardja dan C. M. Witomo. 2008. Riset Identifikasi, Karakterisasi dan Valuasi Sosial Ekonomi Sumber daya Perairan Umum Daratan. Laporan Teknis Kegiatan Penelitian. Balai Besar Riset Sosial Ekonomi Kelautan dan Perikanan. BRKP

Thesis, Disertasi :

Sufii, S. 2008. Konvergensi Ekonomi Regional di Indonesia Tahun 1985-2006. Thesis. Fakultas Ekonomi. Universitas Indonesia. Program Magister Perencanaan dan Kebijakan Publik. Jakarta

Tabel

Judul tabel (Arial, center, \& $11 \mathrm{pt}$ ) diberi nomor urut dan ditulis di atas tabel. Tabel ditulis dalam bahasa Indonesia dan Inggris, diketik menggunakan program MS-Word dan tidak dalam bentuk JPEG. Sumber dicantumkan di bawah tabel.

Contoh:

Tabel 8. Total Nilai Ekonomi Mangrove di Wilayah Pesisir Kabupaten Merauke.

Table 8. The Total Economic Value Mangrove Coastal Merauke.

\begin{tabular}{lrr}
\hline \multicolumn{1}{c}{$\begin{array}{c}\text { Kategori Nilai Ekonomi/ } \\
\text { Category Economic Value }\end{array}$} & $\begin{array}{c}\text { Total Nilai/ } \\
\text { Total value (Rp/Tahun) }\end{array}$ & $\begin{array}{c}\text { Total Nilai/ } \\
\text { Total value (Rp/Ha/Tahun) }\end{array}$ \\
\hline Nilai Guna Langsung/ Direct value & $121,120,873,947$ & $11,964,919$ \\
Nilai Guna Tidak Langsung/ Indirect Value & $48,361,817,303,4$ & $4,777,419$ \\
Nilai Pilihan/ Option value & $3,074,276,220$ & 303,692 \\
Nilai Keberadaan/ The existence value & $2,134,333,320$ & 210,840 \\
Nilai Pewarisan/ Value Inheritance & $2,728,107,120$ & 269,496 \\
\hline \multicolumn{1}{c}{ Total/ Total } & $\mathbf{1 7 7 , 4 1 9 , 4 0 7 , 9 1 0}$ & $\mathbf{1 7 , 5 2 8 , 3 6 7}$ \\
\hline
\end{tabular}

Sumber/ Source : Data Primer Diolah (2015)/ Primary Data Processed (2015)

\section{Gambar}

Judul Gambar (Arial, center, \& 11 pt) diberi nomor urut dan ditulis di bawah Gambar. Gambar ditulis dalam bahasa Indonesia dan Inggris, diketik menggunakan program MS-Word dan dalam bentuk JPEG dengan kualitas gambar resolusi diatas $72 \mathrm{dpi}$. Sumber dicantumkan di bawah judul.

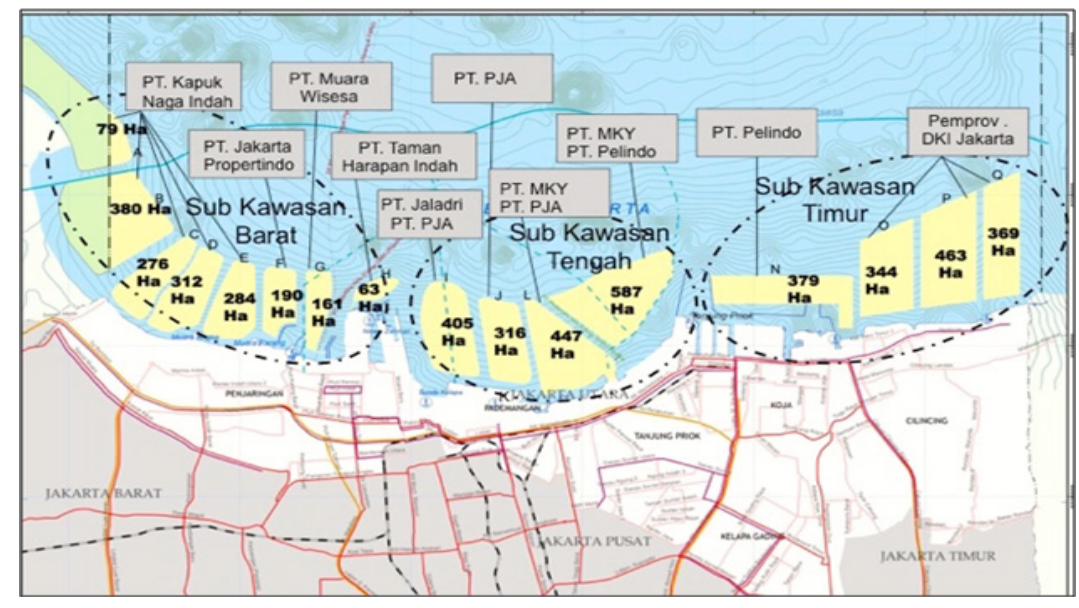

Gambar 1. Peta Wilayah Reklamasi Teluk Jakarta

Figure 1. Map of Reclamation Area of Jakarta Bay

Sumber: Kementerian Lingkungan Hidup dan Kehutanan (KLHK) dalam Mongabay/ Source: Ministry of Environmental and Forestry in Mongabay (2016) 

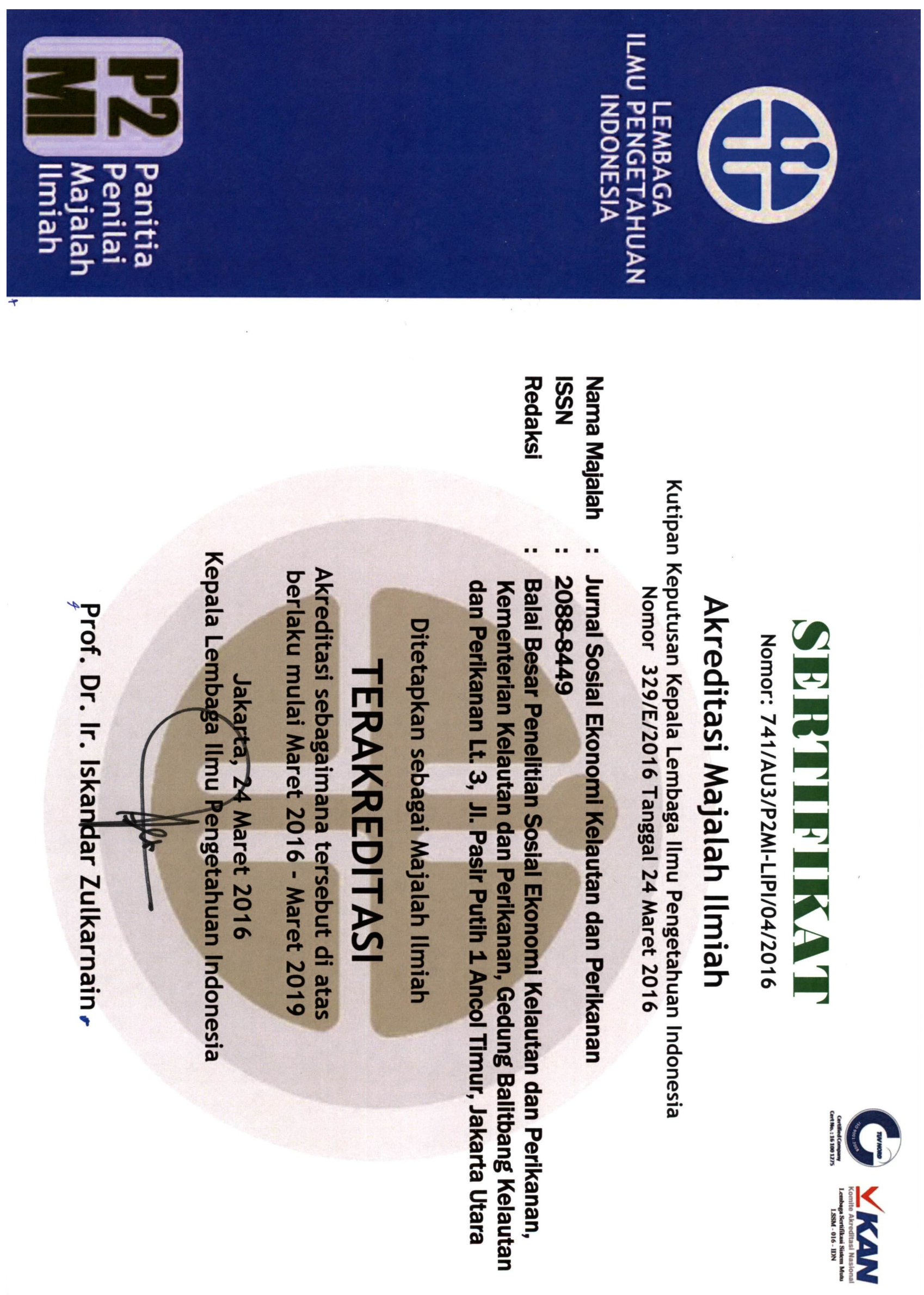


\section{PUSAT PENELTILAY SOSIAL EKONOMI KELAUTAN DAN PERIKAMAK}

Gedung Balitbang Kp Lt. 3

Jalan Pasir Putin Nomor 1 Ancol Timur, Jakarta Utara

Telp : (821) 64711583 Fax.: 64700924

Web : http://bbpse.litbang.kkp.go.id/

Email: pt.sosek@gmail.com

http://ejournal-balitbang.kkp.go.id/index.php/sosek

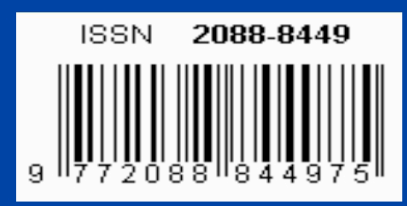

